\title{
ORÍGENES CULTURALES Y SOCIALES DE LA VIOLENCIA
}

FELIPE MARTINNEZ RIZO

Departamento de Educación/UAA

Richard E. NisBetT y Dov Cohen, Culture of Honor. The Psychology of Violence in the South, Boulder, Co. Westview Press, 1996, XVIII + 119 págs.

E n el ámbito de las ciencias sociales, las discusiones entre partidarios de acercamientos de corte cuantitativo a la investigación y quienes prefieren enfoques de tipo cualitativo han sido un rasgo presente de manera regular, desde hace mucho tiempo, con momentos más o menos agudos.

Las primeras de estas polémicas suelen situarse en la segunda mitad del siglo XIX, cuando la estadística moderna y el concepto de diseño experimental se desarrollaba en Inglaterra, mientras en Alemania se cultivaban las geisteswissenschaften, las ciencias del espíritu. Sin embargo, es posible rastrear versiones anteriores del enfrentamiento desde el siglo XVII. Por otra parte, el gran desarrollo que tuvieron las ciencias sociales en el siglo que estamos por terminar, fue acompañado por episodios recurrentes de las polémicas, que en su último avatar tomaron el nombre de "guerras de los paradigmas", con apasionados partidarios en uno y otro bando. Psicómetras, econometristas, especialistas en análisis de trayectorias o modelos loglineales, y otros usuarios de paquetes estadísticos computarizados, se enfrentan a analistas del discurso y defensoras de la perspectiva de género, frecuentemente en términos que se salen de las corteses formas acostumbradas en el medio.

Por fortuna, el tiempo del acercamiento está llegando. Como es usual en este campo, está dándose en los lugares en que el cultivo de las disciplinas sociales está más desarrollado. El libro que se reseña es un ejemplo de esta tendencia, por lo que podrá ser de interés para los estu- 
diosos que se sienten fatigados por la esterilidad de muchas discusiones metodológicas.

El tema de la violencia ha despertado y sigue despertando mucho interés, alimentado por noticias espectaculares, como las de los asesinatos colectivos perpetrados por niños en algunas escuelas norteamericanas. Algunas regiones del sur de los Estados Unidos tienen la dudosa fama de ser particularmente violentas, y ello ha sido atribuido a varias razones: el factor racial, tanto en el caso de estados que fueron esclavistas como en las áreas con alta proporción de población hispana; el factor social, en el caso de los barrios marginados y ghettos, tanto de los centros urbanos deprimidos como de algunos suburbios; incluso factores geográficos y climáticos se aducen como explicaciones: cuando hace calor se cometen más crímenes.

A partir de su éxito en antropología, también en este campo estuvieron en boga corrientes culturalistas durante el segundo tercio del siglo, las que fueron abandonadas a fines de los años 50 y principios de los 60. El principal autor de la obra que nos ocupa, Richard E. Nisbett, opina que lo anterior se debió a dos factores: por una parte, a la competencia de otras corrientes que se pusieron de moda en las ciencias sociales por esa época, como el estructuralismo y el marxismo; por otra, a la debilidad metodológica del culturalismo que, con herramientas muy elementales, tenía inclinación a proponer construcciones teóricas muy ambiciosas con un sustento empírico elemental. El éxito de las obras de Margaret Mead y su posterior rechazo ilustran el punto.

El culturalismo, en opinión de Nisbett, puede todavía aportar elementos valiosos para explicar ciertos fenómenos, y los avances en el campo de la metodología pueden permitirle hacerlo con mayor consistencia que en el pasado.

En su estudio de la violencia en los estados del sur de los Estados Unidos, Nisbett y Cohen comienzan por verificar si es verdad o no que ese tipo de manifestaciones sociales son más frecuentes en esos lugares que en otros. Para ello efectúan análisis estadísticos secundarios de datos censales y de archivo disponibles, pero lo hacen de manera rigurosa y fina, controlando las variables pertinentes para descartar apariencias engañosas.

De la misma manera, proceden para descartar explicaciones espurias, como la que atribuye la violencia a las elevadas temperaturas veraniegas de ciertos lugares, o las que la asocian sin más con variables de raza o grupo étnico sin controlar nivel socioeconómico, tamaño de la localidad y otros factores pertinentes. 
Una vez detectado el fenómeno con precisión, y detectado el carácter espurio de las explicaciones superficiales usuales, Nisbett y Cohen proceden, a su vez, a indagar sobre posibles explicaciones causales más consistentes.

Su estudio incluye aspectos jurídicos, mostrando cómo las leyes o, más precisamente, los criterios de jurisprudencia de aplicación general en lugares del norte y del sur de los Estados Unidos son, efectivamente, muy distintos, admitiendo ciertas formas de violencia con mucha mayor facilidad en el sur.

Los elementos culturales se refieren a diversos estilos de educación familiar, contrastando los casos de los hogares en los que se enseña al niño a pelear, premiando el triunfo y castigando la derrota, se valora la dureza física, se desarrolla el hábito de manejar armas y se desprecia la cobardía, frente a las familias en donde las armas son desconocidas e incluso se descartan los juguetes bélicos, se fomenta la tolerancia y se practican formas pacíficas de resolver los conflictos.

Acudiendo a la historia, Nisbett y Cohen rastrean los estudios sobre las llamadas "culturas del honor", donde se dan los rasgos culturales propicios a la violencia antes mencionados, encontrando que ese tipo de rasgos ocurren predominantemente en sociedades con dos carac- terísticas: tener una economía basada en bienes que pueden robarse fácilmente (como es el caso de los pueblos pastores y ganaderos frente a los agricultores) y carecer de un estado fuerte que proteja a los ciudadanos. En estos lugares la "cultura del honor", el saber defenderse por sí mismo, constituye, en opinión de nuestros autores, un rasgo necesario para la supervivencia.

Nisbett y Cohen encuentran que es frecuente que los pobladores de los lugares donde se manifiestan índices elevados de violencia en la actualidad hayan migrado a partir de lugares marginales del Imperio Británico, como Irlanda y Escocia, donde había sociedades con rasgos de las "culturas del honor", como se han encontrado también en sociedades mediterráneas del norte de África y el sur de Europa, como Grecia, Sicilia y el sur de España.

Para someter a prueba experimental sus hipótesis, los investigadores recurrieron a ingeniosos diseños en los que se puso a sujetos con características sociales y personales controladas, y diferencias en lo relativo al tipo de educación familiar y de "cultura". Expuestos a situaciones aparentemente accidentales de agresión, las reacciones físicas de los sujetos. manifestadas en los niveles de cortisona y testosterona en la saliva mostraron cla- 
ras diferencias entre sujetos educados en un entorno de "cultura del honor" y los demás.

Otras facetas del estudio muestran igual ingenio en su concepción, como estudios de la cobertura de ciertos delitos por los medios de comunicación de diversas regiones, o la manera en que empleadores potenciales valoran supuestos antecedentes criminales de los solicitantes de un puesto de trabajo.
La lectura de la obra de Nisbett y Cohen puede dejarnos una enseñanza muy valiosa, en el sentido de que la apertura que lleva a combinar los más diversos acercamientos metodológicos en un trabajo, con imaginación y rigor, es mucho más productiva que las discusiones sin fin en que ponderamos las bondades de nuestras estrategias, al tiempo que desta'camos las limitaciones del enfoque del vecino. 중 